\title{
Moderating Effect of Planning on the Relationship between Administration of Devolved Water Services and Water Provision in Arid and Semi-Arid Lands in Kenya
}

\author{
Mohamud Mohamed Gedi ${ }^{1}$, Michael Ngala ${ }^{1} \&$ Leonard Wambua ${ }^{1}$ \\ ${ }^{1}$ School of Management and leadership, Management University of Africa, Nairobi, Kenya \\ Correspondence: Mohamud Mohamed Gedi, School of Management and leadership, Management University of \\ Africa, Nairobi, Kenya. E-mail: mohamudgedi@yahoo.com
}

Received: September 6, 2019

doi:10.5539/ijbm.v14n10p214

\begin{abstract}
The Government of Kenya introduced Sessional Paper no 10 in 1965 that stated that for the economy to grow as a whole and as fast as possible, development money should be invested where it will yield the largest increase in net output. It further stated that this approach favored development of areas with abundant natural resources, good land and rainfall, transport and power facilities and people receptive to and active in development. For many years, this statement guided direction of government resources hence neglecting ASAL areas. Even though, and with promulgation of Constitution (2010), Kenya as a water scarce country did devolve water provision to counties, the question of whether administration of devolved water services has assisted in solving challenges related to water provision as desired and anticipated by target six (6) of the Sustainable Development Goals (SDGs) as well as Kenya's Vision 2030 still remain unresolved. The purpose of this study was therefore to establish the moderating effect of planning on the relationship between administration of devolved water services and water provision in ASAL in Kenya. The study used positivism research orientation.Cross- sectional survey research design was adopted. The target population entailed the 113 sub-counties in ASAL where a sample of 89 sub-counties was targeted. Questionnaire helped in collecting primary data. Secondary data collection was done via desk study. planning has a significant moderating effect on the relationship between administration of devolved water services and health-care service delivery in Arid and Semi-Arid Lands in Kenya given that $\Delta \mathrm{R}^{2}=0.003, \Delta \mathrm{F}(1,70)=25.1907, \mathrm{~b}=0.763, \mathrm{t}(72)=5.824$, $\mathrm{p}$-Value $=0.000<0.05$. Findings of this study would contribute useful information that would help in the formulation of an action plan for sustainable water management and conservation in the devolved systems in ASAL in Kenya and the entire country in general. From the findings, the study recommended the need to improve water conservation, protection of catchments and water sources. It should be ensured that there is effective, efficient and sustainable management of both urban and rural water services.
\end{abstract}

Keywords: administration of devolved water services, planning, water provision

\section{Introduction}

Water is the source of life, the most precious and important of all-natural resources, without which the human species cannot survive (DSS, 2010). However, millions of people worldwide are still victims of water scarcity given that the resource falls short of the desired physical accessibility, affordability, quality, reliability, salinity, and clarity which in turn make consumers susceptible to a range of water-borne disease. The sustainability rate on water projects in developing countries is alarmingly low due to a lack of resources, capabilities and spare parts for service and maintenance (Hazelton, 2015). However, in most Arid and Semi-Arid Lands of the developing world, safe drinking water from an improved source remains unacceptably lacking (WHO-UNICEF 2014).

Devolution is a concept that is globally applied with intention of improving administration of public resources while perceived and implemented as a measure for enhancing the provision of social services, through the allowance of a closer linkage of local area needs with the public policy (World Bank, 2012). Some African countries that have embraced this form of decentralization include Uganda, South Africa, Ethiopia, Mali, Tanzania, Mozambique, Kenya, Nigeria and Ghana (Riedl \& Dickovick, 2010). Despite the importance of these 
issues in the political agenda, water policies in many countries do not promote the creation of appropriate institutions to manage water needs and enhance supply and maintenance capabilities (Saleth \& Dinar, 2013). This therefore calls for a more effective mode of policies and that is closer to the community such as devolved governance.

Kiprono and Wanyoike (2016) affirm that development is related to the availability of water, with this relationship being connected to the association between poverty and water availability, which is common in rural regions. Water provision is a complex subject that entails using little but achieving much. In this regard, the administration of devolved water services is expected to enhance water provision and eventually improve the lives of the citizens in ASAL. This is through minimizing resource wastage as well as reducing water pollution while using these resources in producing goods and services. This should be at all levels in the value chain and in provision of water (International Environmental Agreements, 2012). The Water Resource Group (2009) warned that inefficient water usage will cause water demand to exceed its supply by forty percent by 2030 . The UNEP (2011) recommends that to address the shortage, it is critical to invest in infrastructure, policies and modern technologies. However, this cannot just happen since it will be subject to the effectiveness of the leadership styles and the planning exercised in the counties. In this regard, this study explored the relationship amongst the transformational leadership, planning and water provision in the Arid and Semi-Arid Lands, before and after devolution.

While there is evidence that administration of devolved water services has improved conditions in ASAL, this study investigates water provision which is inadequately addressed by past studies. A few studies have been conducted on public water provision but whose focus and scope make the suffer from either conceptual gap, contextual gap or methodological gap is either jurisdictions outside Kenya or haven't laid interest in ASAL. These include studies by Peprah, Oduro-Ofori and Asante-Wusu (2015); Wagah, Onyango and Kibwage (2010); Mwendamseke (2016); Wachira (2014); and Cherunya, Janezic and Leuchner (2015). Unfortunately, these studies did not factor in the aspects of planning as a moderating variable and which from the background of this study has turned out as an area that could have significant influence on the relationship between administration of devolved water services and water provision. To address this gap, this study explored the interplay between administration of devolved water services, planning, and water provision in ASAL in Kenyan.

The specific objectives are:

1. To determine the influence of administration of devolved water services on water provision in ASAL in Kenya;

2. To establish the moderating effect of planning on the relationship between administration of devolved water services and water provision in ASAL in Kenya;

The study will be beneficial to several stakeholders. The first beneficiaries will be the government of Kenya as by illustrating the effects of management skills on water provision in ASAL regions, policy makers may use the finding of this study to better align or revise the existing legal framework, policies and the guidelines of devolution process. Further, the findings may influence the national government to develop appropriate policies to enhance devolution processes so as to improve water provision to the public and thus propel the country towards achieving Vision 2030. The second beneficiary will be the county governments. The members of county assembly may use the finding of this study to better align or revise the existing county legal framework, to promote water provision in the counties.

This study finally came up with policy recommendations, which can be used by county assemblies and county executives to improve on management and leadership skills so as to increase water provision in county governments. The third beneficiary will be the society as the findings of this study may also benefit the entire Kenyan society including private practitioners by providing them with in-depth understanding of the relationship between devolution and water provision delivery. Similarly, the finding of this study will be of significance to other African developing countries and especially the members of the East African community, that are culturally, economically, and politically similar to Kenya. The last beneficiary will be the scholars and researchers as the framework developed in the study may be useful tool to academicians and other researchers wishing replicate this study in different states, counties and countries. Nevertheless, this study serves as a stepping stone for newer research on devolution, planning, planning function and water provision.

\subsection{Importance of the Problem}

Water is the backbone for all known forms of life and therefore it is important to ensure adequate supply in the right quantity and quality. The Government of Kenya recognizes that for the country to meet its 
poverty-reduction strategies and achieve the SDGs, water has to be made available, accessible and affordable, especially to the poor. This is based on the fact that all the seventeen SDGs are directly or indirectly related to access to water. The Kenyan water sector has for a long time been characterized by inefficiencies, lack of investments, poor management and confusing array of legal and institutional frameworks. This has resulted to inadequacies in water accessibility, affordability, quality, reliability, and clarity as well as frequencies to which these water is provided to Arid and Semi Arid Lands. In addition, the exponential growth of Kenya's urban centers has put increasing pressure on utilities to extend services to new areas.

\subsection{Describe Relevant Scholarship}

There are several studies carried out by different scholars in relation to administration of devolved water services, planning and water provision in arid and semi-arid lands in Kenya. A study by Hansen and Villadsen (2010) noted that while there has been a significant amount of studies on planning, there is only a few studies of planning in moderating the relationship between administration of devolved water services and water provision. They compared public and private managers' leadership styles within the framework of their jobs. The study was based on a survey of Danish public and private managers. It examined the impact of the sector within the managerial job context on leadership behavior and suggested that the difference between public and private leadership practices is due to the context of the jobs. The study shows that managers in public and private sector use different leadership styles because they are bound by structural settings of their jobs, role clarity, and perceived job autonomy. According to Hansen and Villadsen (2010), public managers seek to achieve their task through a participative leadership style while private managers use a more directive and task-oriented leadership style. No link of transformational leadership on the relationship between planning and affordability of water in ASAL.

Sorel and Pennequin (2008) advocate for planning to involve developing objectives or the organizational strategic plans and looking for resources that would best be suited in achieving the organizational goals as outlined in strategic plans. Each goal should have financial and human resource projections associated with its completion so that it becomes successful. The planning process also creates timelines for when the plans should be achieved. According to Ballou (2007), planning also involves developing the tracking and assessment method that will be used to monitor the project process. Kibachia, Iravo and Luvanda (2014) have held the view that a common challenge faced by all organizations, whether private or public, is how to successfully manage planning process for attainment of organizational objectives. Planning which is carried out by top management involves formulation of vision and mission statement, performance of situational analysis and finally strategy implementation and choice. The process considers future implications of current decisions, adjusts plans to the emerging business environment, manages the business analytically and links, directs, and controls complex enterprises through a practical, working management system. Robbins, DeCenzo and Coulter (2008) advanced that an effective planning system for an organization links long-range strategic goals with both mid-range and operational plans.

From a review of existing literature, the kind of planning exercised in the counties can affect the degree to which administration of devolved water services enhance the water provision in the society concerned. However, previous studies on devolved services have not adequately addressed this relationship. Due the inadequacies in existing studies, there is a dearth of literature to provide an understanding of the interplay between administration of devolved water services and water provision specifically in ASAL with planning as the moderator.

The study sought to test the following research hypotheses:

$\mathbf{H O}_{1}=$ There is no significant influence of administration of devolved water services on water provision in ASAL in Kenya;

$\mathbf{H O}_{2}=$ There is no significant moderating effect of planning on the relationship between administration of devolved water services and water provision in ASAL in Kenya;

\section{Method}

\subsection{Participant (Subject) Characteristics}

Each sub-county is headed by a Sub-County Water Officer hence the number of sub-counties in ASAL equals the number of Sub-County Water Officers. The total number of respondents was therefore eighty-nine (89). This ensured a naturally heterogeneous but relatively homogeneous sample as recommended by Saifuddin (2009). In the study, questionnaires were administered to Sub-county Water Officer. They were administered through face to face response, where the respondents were asked questions and the researcher recorded the responses in the 
questionnaire. Proportionate sampling was then used to allocate the proportion of the sample size going to each of the 23 counties. Proportions for this study were effectively applied at county level where the number of sub-counties in each county formed the proportion of sample size going to the county. Random sampling was then applied to select sub-counties. The proportions used were computed as Proportion $(\mathrm{P})=$ Sample Size/Total population $=89 / 113=0.787611$. The study applied a cross- sectional survey as its research design. This is because the variables under study were measured as naturally perceived without manipulation or control.

\subsection{Sampling Procedures}

Proportionate sampling was then used to allocate the proportion of the sample size going to each of the 23 counties. Proportions for this study were effectively applied at county level where the number of sub-counties in each county formed the proportion of sample size going to the county. Random sampling was then applied to select sub-counties. The proportions used were computed as Proportion $(\mathrm{P})=$ Sample Size/Total population $=$ $89 / 113=0.787611$. The researcher observed several ethical standards and requirements. A researcher should have integrity in research. Research ethics aims at ensuring that the activities done in the research do not adversely affect or harm anyone (Kayunze, 2003). Before field exercises, the researcher got authorization letter from the Management University of Africa and eventually research permit from NACOSTI, Ministry of Interior and National Coordination in every County in ASAL, as well as office of the County Secretary in the areas of this study.

The researcher made an assurance that, the study findings as derived from the analyzed data would ensure integrity with no manipulation whatsoever. At the same time, all the information that would be obtained from the secondary sources and used in this study would be referenced appropriately. Thus, the research instruments in this study were non-invasive. Moreover, data collected was exclusively used for the academic purpose only. Before distributing the instruments, permission was sought from the leaders and management of Devolved governments in ASAL and other concerned institutions as well as the members of the communities involved in the study.

\subsubsection{Sample Size, Power, and Precision}

The population for this study was 113 sub-countiesin Arid and Semi-Arid lands in Kenya. According to the Ministry of Planning and Devolution Report (2016), there are one hundred and thirteen (113) sub-counties demarcated as Arid and Semi-Arid Lands (ASAL) and distributed within 23 counties in Kenya.

\subsubsection{Measures and Covariates}

This study used questionnaire to collect primary data. Secondary data on the other hand was collected through desk study. For this study, pretesting of the questionnaire was done through piloting to ensure its reliability and consistency. The fundamental importance of piloting is to examine the viability of the anticipated method to be used in the main research (Leon et al., 2011). In general, a $10 \%$ to $20 \%$ of sample size for the main study is recommended for piloting (Osama \&Issa, 2015). In this regard, piloting was conducted on nine sub-counties within ASAL but who were not covered in the final study. This constituted 10.11 percent $(9 / 89)$ which was adequate for the purpose piloting for this study. The study adopted Cronbach Alpha to determine reliability of research instruments.

\subsection{Research Design}

This study used positivism research orientation. Positivism has been dominant in the social, psychological and behavioural sciences as well as management research (Ridenour \& Newman 2008). This study applied a crosssectional survey as its research design. This is because the variables under study were measured as naturally perceived without manipulation or control.

\subsection{Recruitment}

In this study, primary data was collected through and questionnaires. The researcher trained four research assistants who were engaged in collecting primary data. Secondary data was collected by the researcher himself from records on water provision and related issues. This was done by first seeking authority from the relevant county and sub-county authorities in ASALs. For purposes of collecting data in this study, the questionnaires were administered to the relevant respondents in the institutions.

The researcher was also helped by some local recruited residents to administer questionnaires. The local residents have a grasp of the terrain and were readily available.

\subsection{Intervention or Manipulation Fidelity}

The study relied on self-report, audio recorded and observational data. Each of these data collection methods 
provides unique information regarding the adherent and competent implementation of an intervention. Researchers selecting a data collection method for implementation fidelity measurement should consider several factors including, feasibility, cost, efficiency, reliability, reactivity, and the ability to collect adequate behavior samples for measuring practitioner adherence and competence.

\subsection{Baseline Data}

The bio data that was collected includes data on economic activity in the areas studied; as well as respondents' gender, level of education, profession and the year they started working in the county. The main economic activities are Agriculture (54.1\%) and Livestock rearing (45.9\%). However, some also practice Small Scale Business (29.7\%) and Mixed farming (18.9\%). The least practiced economic activities are fishing (2.7\%) and Poultry farming (1.4\%). On respondent's gender, findings indicate that a vast majority of water officers are male (98.6\%) with only $1.4 \%$ being female. On educational level, $39.2 \%$ had a Bachelor degree while $35.1 \%$ had a Diploma. A few had Post Graduate Diploma (8.1\%), with 5.4\% having Master degree Others had Ordinary level (5.4\%); A-Level (4.1\%); PHD (1.4\%). It was apparent that the profession background of an overwhelming majority of the water officers in ASAL Sub Counties is water engineering (95.9\%). Even so, there were few in with a different profession background including accounting (1.4\%), finance (1.4\%) and water technician $(1.4 \%)$. Most of the Sub County Water Officers started working in their respective County governments in $2013(78.4 \%)$. However, there were some who started working in 2014 (10.8\%); 2015 (6.8\%); 2016 (1.4\%) and 2017 (2.7\%)

\subsubsection{Statistics and Data Analysis}

Step-wise regression analysis was used to test the effect of moderating variable on the relationship between independent variable and the dependent variable.

i. $\quad Y_{1}=\beta_{0}+\beta_{1} X_{1}+e$; this analytical model tests the relationship between independent variable (administration of devolved water services) and the dependent variable (water provision).

ii. The analytical model for testing moderating effect of planning $\left(\mathrm{M}_{1}\right)$ on the relationship between administration of devolved water services and water provision:

Step 1: $\mathrm{Y}=\beta_{0}+\beta_{1} \mathrm{X}+\mathrm{e}$

Step 2: $Y=\beta_{2}+\beta_{3} X+\beta_{4} M_{1}+\varepsilon$

Step 3: $Y=\beta_{5}+\beta_{6} X+\beta_{7} M_{1}+\beta_{8} X * M_{1}+\varepsilon$

Where $\boldsymbol{Y}$ is water provision, $\boldsymbol{X}$ is administration of devolved water services, $\boldsymbol{M}_{\boldsymbol{l}}$ is planning, $\mathrm{X} * \mathrm{M}_{1}$ is the interaction term and $\boldsymbol{e}$ is the error term. $\boldsymbol{B}_{\boldsymbol{0}}, \boldsymbol{B}_{2}$ and $\boldsymbol{B}_{5}$ are the constants with $\boldsymbol{\beta}_{1}, \boldsymbol{\beta}_{3}, \boldsymbol{\beta}_{4}, \boldsymbol{\beta}_{6}, \boldsymbol{\beta}_{7}$, and $\boldsymbol{\beta}_{8}$, being the model coefficients (Hayes, 2018).

\section{Results}

\subsection{Administration of Devolved Water Services and Water Provision}

Descriptive statistics were presented on a 5-point Likert-type scale data that was summarized using measure of distribution (percentages) measures of central tendency (mean, mode, and median) as well as measure of dispersal (standard deviation). Values of mean, mode and median that are relatively close to each other describe data that is highly symmetric and normally distributed. At the same time mean was used in this study to rank prevalence of different factors grouped together with high mean indicating high prevalence. On the other hand, larger standard deviation implies a greater spread in the data.

The first objective sought to determine the influence of administration of devolved water services on water provision in ASAL in Kenya. From the findings, administration of devolved water services was found to be highly enhancing the rate at which county government engages local residents to actively participate in water provision decision making processes with mean of 3.64, median of 4.00, mode of 4.00 and standard deviation of 0.97. Respondents, nonetheless distressed that administration of devolved water services in the county has led to increase in the number of water management companies ( mean $=2.43$, median $=2.00$, mode $=1.00$ and standard deviation $=1.24$ ). Findings also indicate that the county leaderships have to a moderate extent been engaging members of their respective county and national assembly's as well as professionals to actively participate in water provision decision making processes including seeking valuable advice on emerging efficient water provision techniques and mechanisms.

The findings imply that human capital in water services provision has been moderately impacted by devolution. Human capital is a key aspect in the manoeuvres of the organization (Armstrong, 2008). Inferential statistics were determined at both composite level and indicators level. Inferential statistics on administration of devolved 
water services at composite level entailed coefficient of determination (R-Square), analysis of variance as well as regression coefficient. Test for autocorrelation was also performed. On the model Summary on Administration of devolved water services it showed an R-Square of 0.89 with the standard error of estimate being 1.13. This implies that at composite level, administration of devolved water services significantly influences water provision. The researcher also tested for autocorrelation using Durbin Watson statistic which was found to be 2.077 and therefore the there was no presence of autocorrelation in the residuals from a regression analysis. On the ANOVA statistics on Administration of devolved water services F-Calculated $(1,72)=582.89$ which is greater than F-Critical $(1,72)=3.96$ at 2 -tail test and $95 \%$ confidence level. Results also show p-value $=0.000<$ 0.005 . This further confirms that administration of devolved water services positively and significantly influences water provision. On the Regression Coefficients on Administration of devolved water services it was that, when administration of devolved water services is held constant, water provision we remain at 1.993. At the same time, an increase in administration of devolved water services by one unit would lead to an increase in water provision by 0.275 units with a p-value of $0.000<0.05$. This can be summarized by the following model $: Y=1.993+0.275 X$

In summary, given R-Square $=0.890$ with F-Calculated $(1,72)=582.777$ which is greater than F-Critical $(1,72)$ $=3.96 \backslash \mathrm{t} 2$-tail test and $95 \%$ confidence level and $p$-value $=0.000<0.05$ as well as a positive elasticity $(0.275)$ the researcher did not accept the null hypothesis $\left(\mathrm{HO}_{1}\right)$ and therefore concludes that there is positive and significant influence of administration of devolved water services on water provision in ASAL in Kenya.

3.2 Moderating Effect of Planning on the Relationship between Administration of Devolved Water Services and Water Provision

The second objective for this study was to establish the moderating effect of planning on the relationship between administration of devolved water services and water provision in Arid and Semi-Arid Lands in Kenya. The moderating effect of planning was assessed and results explained using coefficient of determination (R-Square), Analysis of Variance (ANOVA) and the regression coefficients. Hierarchical regression analysis was performed with an interaction term (a product of planning and administration of devolved water services) introduced as an additional predictor.

Table 1. Regression coefficients when planning is moderating the relationship between administration of devolved water services and water provision

\begin{tabular}{|c|c|c|c|c|c|c|}
\hline \multirow[t]{2}{*}{ Model } & & \multicolumn{2}{|c|}{ Unstandardized Coefficients } & \multirow{2}{*}{$\begin{array}{l}\text { Standardized } \\
\text { Coefficients } \\
\text { Beta }\end{array}$} & \multirow[t]{2}{*}{$\mathrm{T}$} & \multirow[t]{2}{*}{ Sig. } \\
\hline & & $\mathrm{B}$ & Std. Error & & & \\
\hline \multirow[t]{2}{*}{1} & (Constant) & 1.993 & .342 & & 5.827 & .000 \\
\hline & Administration of devolved water services & 0.275 & .011 & 0.943 & 25.000 & .000 \\
\hline \multirow[t]{3}{*}{2} & (Constant) & .474 & .134 & & 3.537 & .000 \\
\hline & Administration of devolved water services & .167 & .006 & .574 & 27.833 & .000 \\
\hline & Planning & .160 & .006 & .485 & 25.003 & .000 \\
\hline \multirow[t]{4}{*}{3} & (Constant) & 0.556 & .085 & & 6.541 & .000 \\
\hline & Administration of devolved water services & 0.164 & .011 & .563 & 14.909 & .000 \\
\hline & Planning & 0.156 & .011 & .476 & 14.182 & .000 \\
\hline & Devolution.Planning & 0.763 & .131 & .020 & 5.824 & .000 \\
\hline
\end{tabular}

Table 1 presents regression coefficients and their significant values for model 1 (direct effect), model 2 (controlling effect) and model 3 (moderating effect). From the unstandardized coefficients, administration of devolved water services was making a unique significant and positive contribution to water provision with planning for all the three models ( $\mathrm{p}$-Value $<0.05$ ). In model 3 , this significance is particularly given by $b=0.164$, $\mathrm{T}_{\text {- } \text { - }}$ alculated $(73,0.05)=14.909>\mathrm{T}-$ Critical $(0.05,73)=1.658$ and $\mathrm{p}$-Value $=0.000<0.05$ for administration of devolved water services; $\mathrm{b}=0.156, \mathrm{~T}_{-}$- alculated $(73,0.05)=14.182>\mathrm{T}$ - Critical $(0.05,73)=1.658$ and $\mathrm{p}$-Value $=0.000<0.05$ for planning; and $\mathrm{b}=0.763, \mathrm{~T}_{-}$- alculated $(73,0.05)=5.824>\mathrm{T}$ - - $r$ itical $(0.05,73)=1.658$ and $\mathrm{p}$-Value $=0.000<0.05$ for interaction term. The autonomous value is 1.764 . The regression model can therefore be summarized as:

$$
Y=0.556+0.164 X+0.156 M_{2}+0.763 X * M_{2}
$$

Where $X * M_{2}$ represents interaction term given as a product of planning $\left(M_{2}\right)$ is interacted with administration of devolved water services (X). 
Table 2. Analysis of variance when planning is moderating the relationship between administration of devolved water services and water provision

\begin{tabular}{llllll}
\hline Model & & Sum of Squares & Df & Mean Square & F \\
\hline 1 & Regression & 740.710 & 1 & 740.710 & 582.777 \\
& Residual & 91.494 & 72 & 1.271 & $.000^{\mathrm{a}}$ \\
& Total & 832.204 & 73 & & $3,140.733$ \\
\multirow{2}{*}{2} & Regression & 822.873 & 2 & 411.436 & $.000^{\mathrm{b}}$ \\
& Residual & 9.332 & 71 & .131 & $2,062.376$ \\
& Total & 832.204 & 73 & & $.000^{\mathrm{c}}$ \\
& Regression & 822.887 & 3 & 274.296 & .133 \\
\end{tabular}

The ANOVA (Table 2) was intended to evaluate if models 1 is significant and if the amount of variance accounted for in Model 3 (moderating effect) is significantly more than Model 2 (controlling effect). Findings indicate that the model 3 is significant given $\mathrm{F}(3,70)=2,062.376, \mathrm{p}=0.000<.05$.

Table 3. Coefficient of determination when planning is moderating the relationship between administration of devolved water services and water provision

\begin{tabular}{|c|c|c|c|c|c|c|c|c|c|}
\hline \multirow[b]{2}{*}{ Model } & \multirow[b]{2}{*}{$\mathrm{R}$} & \multirow[b]{2}{*}{$\mathrm{R}^{2}$} & \multirow[b]{2}{*}{ Adjusted $\mathrm{R}^{2}$} & \multirow[b]{2}{*}{$\begin{array}{l}\text { Std. Error of } \\
\text { the Estimate }\end{array}$} & \multicolumn{5}{|c|}{ Change Statistics } \\
\hline & & & & & $\mathrm{R}^{2}$-Change & F-Change & df1 & df2 & $\begin{array}{l}\text { Sig. } \\
\text { F-Change }\end{array}$ \\
\hline 1 & $.943^{\mathrm{a}}$ & .890 & .889 & 1.127 & .890 & 582.777 & 1 & 72 & .000 \\
\hline 2 & .994 & .989 & .988 & .36253 & .099 & 625.140 & 1 & 71 & .000 \\
\hline 3 & .996 & .993 & .990 & .36484 & .003 & 25.1907 & 1 & 70 & .004 \\
\hline
\end{tabular}

Table 3 presents the percent of variability in the water provision (dependent variable) that can be accounted for by administration of devolved water services and planning (predictors). With introduction of interaction term (model 3), $\mathrm{R}^{2}$ changes (an increase) by 0.003 to 0.993 from 0.989 (model 2) with standard error being 0.365 . This change was significant $(p$-Value $=0.004<0.05$ ) implying that planning had a significant moderating effect on the relationship between administration of devolved water services and water provision in ASAL in Kenya.

In summary and to test the hypothesis that planning does not significantly moderate the relationship between administration of devolved water services and water provision in Arid and Semi-Arid Lands in Kenya, a three-steps hierarchical multiple regression analysis was conducted. In the first step, the independent variable was included: administration of devolved water services and water provision. These variable accounted for a significant amount of variance in water provision, $\mathrm{R}^{2}=0.890, \mathrm{~F}(1,72)=582.777, \mathrm{p}$-Value $0.000<0.05$. Next, the controlling effect was determined which also accounted for a significant effect with $\mathrm{R}^{2}=0.989$, F-Change ( 1 , $71)=625.140, p$-Value $0.000<0.05$. The third and last step entailed introduction of interaction term to the regression model, which accounted for a significant proportion of the variance in water provision, $\Delta \mathrm{R}^{2}=0.003$, $\Delta \mathrm{F}(1,70)=25.1907, \mathrm{~b}=0.763, \mathrm{t}(72)=5.824, \mathrm{p}$-Value $=0.000<0.05$. Consequently, the researcher did not accept the null hypothesis $\left(\mathrm{HO}_{3}\right)$ and therefore concludes that planning has a significant moderating effect on the relationship between administration of devolved water services and health-care service delivery in Arid and Semi-Arid Lands in Kenya.

\section{Findings and Discussion}

This study found a significant moderating role of planning on the relationship between administration of devolved water services and water provision in ASAL. The study findings indicate that County Leaders use strategic plans; County Integrated Development Plans (CDIP). The Counties in ASAL have also developed appropriate structures for water provision from the County Headquarters to lower levels in Sub Counties as well as allocating resources to meet the water demands by residents that has ensured timely delivery of services.

The study findings affirm the assertions by Sifuna (2012) that it is the management that puts into action the formulated goals in the organization. They further echo Hughes et al., (2012) assertion that it is the task of the management in all organizations is to lay down the structure of the organization and the orders to be followed. These functions have been affirmed as necessary in ensuring effectiveness and efficiency of the organization 
(Leung \& Kleiner, 2004). However, in Hirsch (2006) views, issues affecting management of water persist to be highly context-specific hence the approaches used to manage the utilization of water sources may vary from one manager to the other (Owuor \& Foeken, 2009). However, water provision projects have been strongly criticized for their planning approaches, which have focused excessively on physical construction and increasing coverage targets, but largely ignored what happens at the water sources after construction (Lockwood, 2014). For the last few decades, literature in the water supply sector has shown that sustainability of rural water supply structures has become positively associated with small-scale initiatives, which maintain public participation. Thus, the key to sustainability is to meaningfully involve the users in the planning, implementation, operation, protection and maintenance of water supply systems according to their needs and potentials (Davis \& Liyer, 2012). Findings also approves that, improved planning procedures which fully consider the value and demand placed on different levels of service by the community are a necessity for the ownership of rural water projects (Mbata, 2014). However, in spite of the ever-increasing importance placed on the role of participation in development efforts, there have been few quantitative studies to demonstrate the proposition that participation measurably increases development outcomes (Prokopy, 2015).

Water management is particularly dependent on strong capacity, a solid knowledge base and awareness at all levels, including those of the individual, the organization, the sector institutions and the 'enabling environment'. Yet getting all levels to operate in a coherent manner is challenging, and requires vision and leadership. Leadership is needed to improve cooperation and interaction between interdependent water uses such as food, energy, industry and the environment in order to increase water security and promote sustainable development.

The respondents further reported that planning at the County is inclusive formal process and stakeholder participation is an integral part of the water provision in ASAL. This has been possible where the National Government, independent commissions, development partners, general public, the representatives of the business community, employees, financial partners, and the County executive participate in planning through public consultative meetings and forums organized by the County's planning. Findings in this study effectively advocates for improved planning procedures which fully consider the value and demand placed on different levels of service by the community are a necessity for the ownership of rural water projects (Mbata, 2014). However, in spite of the ever-increasing importance placed on the role of participation in development efforts, there have been few quantitative studies to demonstrate the proposition that participation measurably increases development outcomes (Prokopy, 2015).

As advocated by Sorel and Pennequin (2008), planning should involve developing objectives or the organizational strategic plans and looking for resources that would best be suited in achieving the organizational goals as outlined in strategic plans. Each goal should have financial and human resource projections associated with its completion so that it becomes successful. The planning process also creates timelines for when the plans should be achieved. According to Ballou (2007), planning also involves developing the tracking and assessment method that will be used to monitor the project process. Daft and Marcic (2016) emphasize the primacy of planning among the manager's tasks. Hence, planning logically precedes the execution of all the other managerial functions. Awino et al. (2012) argues that the more emphasis there is on planning, the greater the positive change in firm's performance. Planning is typically where the direction of the organization is established through a variety of activities including the development of goals. As such, the planning embodies various levels of decision making (Schraeder, et al. 2015).

These findings therefore support the contention that planning provides the basic direction and rationale for determining the focus of an organization; and also provides the specification against which any organization may best decide what to do and how to do it. Planning is simply defined as a process for creating and describing a better future in measurable terms and the selection of the best means to achieve the results desired. It is said that failure to plan is akin to planning to fail. Thus, Abdalkrim (2013) summarized the importance of planning as; the increase in effectiveness, development of a sustainable competitive position, developing a good fit between the external environment and the internal capabilities and helping managers to consider the future implications of the current decisions. Having a good vision, objective and strategy is no guarantee that the project performance will be good. Creative planning by the management can help in improving performance outcome of the project. But on the other side, without a vision, good plan or strategy, the performance of a project is sure to fail or at best will be poor.

\subsection{Improvements Needed Regarding Planning in Water Provision}

Analysis was done using R-based Qualitative Data Analysis (RQDA) software and results presented in bar plot (Figure 1). 


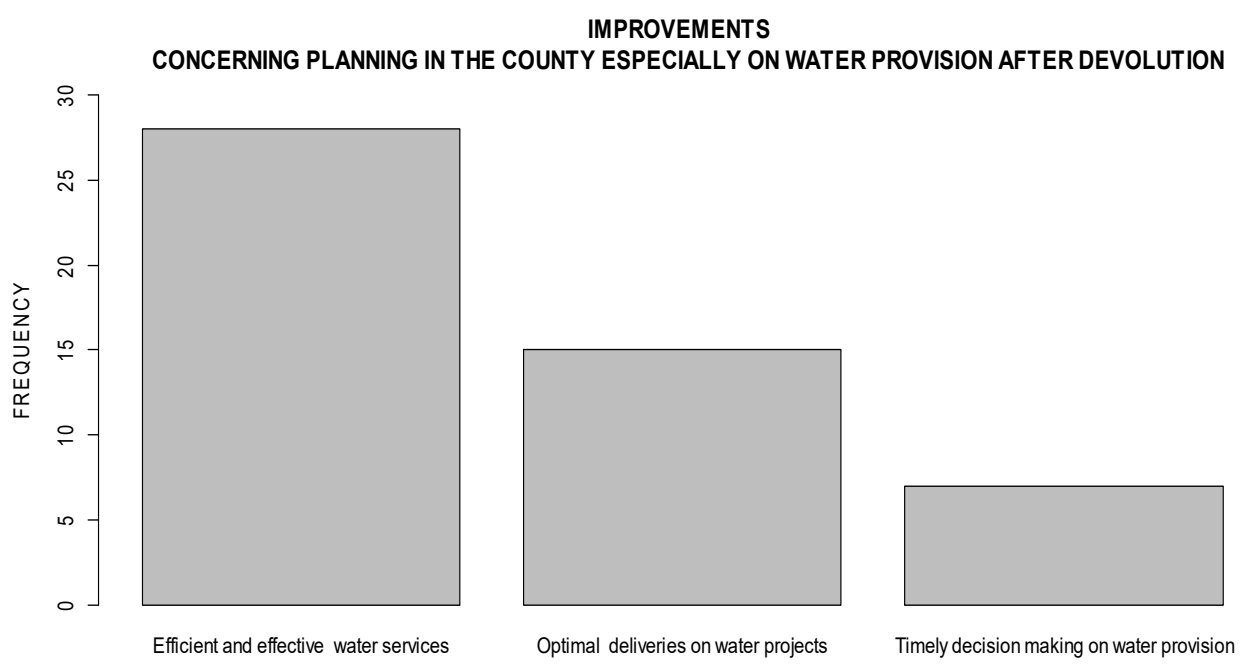

Figure 1. Bar Chart presenting improvements needed regarding planning in water provision

Respondents mentioned that efficient and effective management of water services, optimal deliveries on water projects, and timely decision making on water provision, more so in administration of devolved water services, are the key elements of planning that would improve water provision in ASAL as summarised in Figure 1. This can only be achieved if devolved leadership ensure that skills of the staff are matched to their designated responsibilities in the county and ensure appropriate structure are being created as well as enhancing appropriate allocation of resources in county budget towards waste project. Moreover, respondents indicated that county government should train the community on the management of water facilities to improve their skills while Identification of water projects should be demand driven and not political mileage. Over and above, more effort for improvement should be done especially in water distribution systems besides increasing qualified staff in the water administrative field and undertaking adequate induction and trainings. This implies that, for planning to be effective in moderating the relationship between administration of devolved water services and water provision, trainings and availability of resources need to be employed. Water technician and professionals should be given chance to manage water provision facilities while devolution should be extended to sub-county level. For policy making purpose, passing of Water and Sanitation Bills should be fast tracked and passed to county assembly.

\section{Conclusion and Recommendation}

In conclusion the two study objectives were achieved and their respective null hypothesis not accepted. The first objective was to determine the influence of administration of devolved water services on water provision in ASAL in Kenya. The second objective was to establish the moderating effect of planning on the relationship between administration of devolved water services and water provision in ASAL in Kenya. Planning was found to have been at the center of success in administration of devolved water services and water provision given that changes in water provision has significantly been explained by administration of devolved water services when planning is factored in. The study revealed that county leaders clarify and gain consensus on the vision and mission in water provision and the need for planning. Devolution was therefore affirmed to have enabled optimal and on-time deliveries on water projects to a great extent.

\section{Acknowledgements}

My sincere gratitude goes to my family and friends due to the support they accorded me in my study. I also express earnest appreciation to my supervisors Dr. Leonard Wambua and Dr. Michael Ngala because they have assisted me by providing direction and guidance. My special appreciation also goes to the entire teaching and non-teaching staff of the School of Management and Leadership whose contribution and support have helped me reach this far in my studies. God bless you all.

\section{References}

Abdalkrim, G. M. (2013). The impact of strategic planning activities on private sector organizations performance in Sudan: An empirical research. International Journal of Business and Management, 8(10), 134.

Awino, Z. B., Muturia, J. M., \& Oeba, L. K. (2012). Strategic planning, Planning outcomes and organizational 
Performance.

Cherunya, P. C., Janezic, C., \& Leuchner, M. (2015). Sustainable supply of safe drinking water for underserved households in Kenya: Investigating the viability of decentralized solutions. Water 2015, 7(10), 5437-5457. https://doi.org/10.3390/w7105437

Daft, R. L., \& Marcic, D. (2016). Understanding Management. Mason, OH: South-Western, Cengage Learning.

Davis, J., \& Liyer, P. (2012). Taking Sustainable Rural Water Supply Services to Scale: A Discussion Paper. Bank of Netherlands Water Partnership Energy and Water Department, World Bank, Washington DC.

Hansen, J. R., \& Villadsen, A. R. (2010) Comparing public and private managers' leadership styles: Understanding the role of job context. International Public Management Journal, 13(3), 247-274, https://doi.org/10.1080/10967494.2010.503793

Hazelton, D. (2015). The development of community water supply systems using deep and shallow well hand pumps. WRC Report No, TT132/00, Water Research Centre, South Africa.

Hirsch, P. (2006). Water governance reform and catchment management in the Mekong region. The Journal of Environment \& Development, 15(2), 184-201

Kayunze, K. (2003), Social Science Research Methods - DS 300 Notes. Development Studies Institute, Sokoine University of Agriculture, Morogoro.

Kibachia, K., Iravo, M., \& Luvanda, A. (2014). A survey of risk factors in the strategic planning process of parastatals in Kenya, European Journal of Business and Innovation Research, 2(3), 51-67.

Kiprono, P., \& Wanyoike, D. (2016). Influence of selected County Governments funded projects on the living standards of the beneficiaries. A survey of Kericho County, Kenya. International Journal of Economics, Commerce and Management, 4(5), 579-590.

Leung, J., \& Kleiner, B. H. (2004). Effective management in the food industry. Management Research News, $27(4 / 5), 72-81$.

Lockwood, H. (2014). Institutional Support Mechanisms for Community-Managed Rural Water Supply and Sanitation Systems in Latin America, Prepared for the Bureau of Latin American and the Caribbean USAID under EHP Project.

Mbata, J. (2014 ). Estimating Household Willingness for Water Services in Rural economy: the Case of Kanye in Southern Botswana. Development of Southern Africa, 23(1), 29-43.

Mwendamseke, E. (2016). Assessment of Community-Owned Water Supply Organizations (COWSOs) Strategy for Sustainability of Rural Water Supply in Dodoma Region

Owuor, S. O., \& Foeken, W. J. (2009). Water reforms and interventions in urban Kenya: Institutional set-up, emerging impact and challenges. ASC Working Paper 83/2009: Leiden: African Studies Centre.

Peprah, C., Oduro-Ofori, E., \& Asante-Wusu, I. (2015). Analysis of accessibility to water supply and sanitation services in the Awutu-Senya East Municipality, Ghana. Journal of Sustainable Development, 8(8), 310-325.

Prokopy, S. (2015). The Relationship between Participation and Project Outcomes Projects in India: Evidence from Rural Water Supply. World Development, 33(11), 1801-1819.

Ridenour, C. S., \& Newman, I. (2008). Mixed Methods Research: Exploring the Interactive Continuum. Carbondale, IL: Southern Illinois University Press.

Riedl, R. B., \& Dickovick, T. J. (2010). Comparative Assessment Of Decentralization In Africa: Final Report And Summary Of Findings. Washington, D.C.: United States Agency for International Development.

Robbins, S. P., DeCenzo, D. A., \& Coulter, M. K. (2008). Fundamentals of management: essential concepts and applications. Upper Saddle River, NJ: Pearson Prentice Hall.

Saleth, M., \& Dinar. A. (2013). The Institutional Economics of Water: A Cross Country Analysis of Institutions and Performance. Washington, DC, and Northampton, MA, USA: World Bank and Edward Elgar

Schraeder, M., Self, D. R., Jordan, M. H., \& Portis, R. (2015). The Functions of Management as Mechanisms for Fostering Interpersonal Trust. Advances in Business Research, 5(1), 50-62.

Sifuna, D. N. (2012). Leadership in Kenyan public universities and the challenges of autonomy and academic freedom: An overview of trends since independence. JHEA/RESA, 10(1), 121-137.

Sorel, O., \& Pennequin, V. (2008). Aging of the planning process: The role of executive functioning. Brain and 
cognition, 66(2), 196-201.

UNEP (2011). United Nations Permanent Forum on Indigenous Issues (UNPFII), United Nations, New York

Wagah, G. G., Onyango, G. M., \& Kibwage, J. K. (2010). Accessibility of water services in Kisumu municipality, Kenya. Journal of Geography and Regional Planning, 3(4), 114-125

Water Resources Group. (2009). Charting Our Water Future, Economic Frameworks to Inform Decision-making: Executive Summary. Retrieved from http://www.mckinsey.com/clientservice/water/charting_our_water_future.aspx

Who-Unicef. (2014). Joint Monitoring Programme for Water and Sanitation. Retrieved from http://www.wssinfo.org/en/238_wat_latino.html

World Bank. (2012). Devolution without Disruption - Pathways to a Successful New Kenya. Nairobi: World Bank

\section{Research Questionnaires}

This questionnaire seeks to collect data to assist in conducting a study on 'The Effect of Administration of devolved water services on Water provision in ASAL.' The data that you provide herein will remain confidential and will be strictly for academic use. Please give honest responses in every question.

\section{Instructions}

Do Not write your name anywhere on this questionnaire.

Where choices are given, kindly tick $(\sqrt{ })$ inside the relevant box to indicate the correct answer. Otherwise, write your answer in the spaces provided where there are no options given.

\section{SUB-COUNTY BIO-DATA}

i) Name of your County (Optional)

ii) Name of your Sub-County (Optional)

iii) How many wards are in this Sub-County?

iv)What is/are the main economic activity/activities in this Sub-County? (Tick all the applicable options)

Crop Farming [ ] Zero grazing [ ]

Nomadic Pastoralism [ ] Fish Farming [ ] Any other (Specify)

\section{SECTION A: BACKGROUND}

1) Please indicate your gender by ticking the appropriate option

Male ( ) Female ( )

2) Kindly indicate your age bracket by ticking the appropriate option

25 years and below ( ) 26 to 35 years ( )

36 to 45 years ( ) 46 to 55 years ( ) Over 55 years $($ )

3) What is your highest education level? (please tick the appropriate option) University level ( ) College level ( ) A-Level ( )

Ordinary level ( ) Primary level ( ) Any other (Specify)...

4) When did you start working for the county leadership? (please tick the appropriate option) 2013 ( ) 2014 ( ) 2015 ( ) 2016 ( ) 2017 ( )

\section{SECTION B: ADMINISTRATION OF DEVOLVED WATER SERVICES}

5) From your experience in county leadership, to what extent does the governor engage the following stakeholders in the making and implementation of water provision decisions in county leadership? Please rate by writing a number from 1 to 5 where Not at all=1, Low extent $=2$, Moderate extent $=3$, Great extent $=4$ and Very great extent $=5$. 


\begin{tabular}{|l|l|l|l|l|l|}
\hline Aspect & $\begin{array}{l}\text { Very great } \\
\text { extent }\end{array}$ & $\begin{array}{l}\text { Great } \\
\text { extent }\end{array}$ & $\begin{array}{l}\text { Moderate } \\
\text { extent }\end{array}$ & $\begin{array}{l}\text { Low } \\
\text { extent }\end{array}$ & $\begin{array}{l}\text { Not at } \\
\text { all }\end{array}$ \\
\hline Investors & & & & & \\
\hline Property developers & & & & & \\
\hline Professionals & & & & & \\
\hline Members of county leadership Assembly & & & & & \\
\hline The senator & & & & & \\
\hline Members of County Assembly & & & & & \\
\hline Woman representative & & & & & \\
\hline Ordinary local residents & & & & & \\
\hline Any other (Specify).... & & & & & \\
\hline
\end{tabular}

6) To what extent does the County Executives display the following barriers to stakeholders' engagement on matters involving water provision? Please rate by writing a number from 1 to 5 where Not at all=1, Low extent $=2$, Moderate extent $=3$, Great extent $=4$ and Very great extent $=5$.

\begin{tabular}{|l|l|l|l|l|l|}
\hline Aspect & $\begin{array}{l}\text { Very great } \\
\text { extent }\end{array}$ & $\begin{array}{l}\text { Great } \\
\text { extent }\end{array}$ & $\begin{array}{l}\text { Moderate } \\
\text { extent }\end{array}$ & $\begin{array}{l}\text { Low } \\
\text { extent }\end{array}$ & $\begin{array}{l}\text { Not at } \\
\text { all }\end{array}$ \\
\hline $\begin{array}{l}\text { Insufficient clarity on how to involve } \\
\text { stakeholder inputs }\end{array}$ & & & & & \\
\hline Insufficient political will and leadership & & & & & \\
\hline Insufficient time, staff and or funding & & & & & \\
\hline Weak supportive legal frameworks & & & & & \\
\hline $\begin{array}{l}\text { Resistance to change and reluctance to } \\
\text { relinquish power }\end{array}$ & & & & & \\
\hline Any other (specify) & & & & & \\
\hline
\end{tabular}

7) From your experience while working in this county, kindly indicate the extent to which you agree with the following statements on a scale of 1 to 5 . Please rate by writing a number from 1 to 5 where Not at all=1, Low extent $=2$, Moderate extent $=3$, Great extent $=4$ and Very great extent $=5$.

\begin{tabular}{|l|l|l|l|l|l|}
\hline Statement & $\begin{array}{l}\text { Very } \\
\text { great } \\
\text { extent }\end{array}$ & $\begin{array}{l}\text { Great } \\
\text { extent }\end{array}$ & $\begin{array}{l}\text { Moderate } \\
\text { extent }\end{array}$ & $\begin{array}{l}\text { Low } \\
\text { extent }\end{array}$ & $\begin{array}{l}\text { Not } \\
\text { at } \\
\text { all }\end{array}$ \\
\hline $\begin{array}{l}\text { The residents from all sub-counties are engaged by the County } \\
\text { Governments in making water provision decisions in county } \\
\text { leadership }\end{array}$ & & & & & \\
\hline $\begin{array}{l}\text { My county leadership takes into account the opinions raised by } \\
\text { the residents while implementing water provision decisions }\end{array}$ & & & & & \\
\hline $\begin{array}{l}\text { My county leadership has put in place adequate platforms for } \\
\text { all stakeholders to give their opinions concerning water } \\
\text { provision in county leadership }\end{array}$ & & & & & \\
\hline $\begin{array}{l}\text { My county leadership ensures both men and women have } \\
\text { adequate opportunities to give their opinions on issues affecting } \\
\text { water provision in county leadership }\end{array}$ & & & & & \\
\hline $\begin{array}{l}\text { Issues concerning water provision are effectively communicated } \\
\text { to all stakeholders in county leadership }\end{array}$ & & & & & \\
\hline
\end{tabular}


8) In your opinion, what suggestions would you give concerning stakeholder's engagement in county leadership?

From your experience while working in this county and in comparison, before and after water service was devolved to be managed at county level by Kenya Government in 2013, kindly indicate the extent to which you agree with the statements listed in the table below on a scale of 1 to 5 . Please rate each statement by ticking $(\sqrt{ })$ appropriate option against each statement provided, where $1=$ Not at all, $2=$ Low extent, $3=$ Moderate extent, 4 $=$ Great extent and $5=$ Very great extent.

\begin{tabular}{|l|l|l|l|l|}
\hline Statement & $\begin{array}{l}\text { Very } \\
\text { great } \\
\text { extent } \\
\text { Human resource development }\end{array}$ & $\begin{array}{l}\text { Great } \\
\text { rate } \\
\text { extent }\end{array}$ & $\begin{array}{l}\text { Modent } \\
\text { extent } \\
\text { at } \\
\text { all }\end{array}$ \\
\hline $\begin{array}{l}\text { There is recruitment of adequate employees to manage water } \\
\text { services in the County }\end{array}$ & $\begin{array}{l}\text { Not } \\
\begin{array}{l}\text { There is enhanced principle of meritocracy such that the staff } \\
\text { recruited possess the requisite skills, knowledge and experiences to } \\
\text { competently manage water services in county }\end{array}\end{array}$ & & & \\
\hline $\begin{array}{l}\text { There is enhanced level of staff commitment in their work related } \\
\text { to water services }\end{array}$ & & & & \\
\hline $\begin{array}{l}\text { There is enhanced the level of professionalism among water } \\
\text { service personnel }\end{array}$ & & & & \\
\hline $\begin{array}{l}\text { There is enhanced transparency and accountability in procurement } \\
\text { processes for water service providers }\end{array}$ & & & & \\
\hline $\begin{array}{l}\text { There is enhanced the level of integrity and prudence in } \\
\text { management of water service resources among county and } \\
\text { sub-county administrators }\end{array}$ & & & & \\
\hline
\end{tabular}

9) What recommendations would you give concerning human resource development in the county?

From your experience while working in this county and in comparison, before and after water service was devolved to be managed at county level by Kenya Government in 2013, kindly indicate the extent to which you agree with the statements listed in the table below on a scale of 1 to 5 . Please rate each statement by writing a number from 1 to 5 where $\mathbf{1}=$ Not at all, $\mathbf{2}=$ Low extent, $3=$ Moderate extent, $4=$ Great extent and $5=$ Very great extent.

\begin{tabular}{|c|c|c|c|c|c|}
\hline $\begin{array}{l}\text { Statement } \\
\text { Application of Modern Technology }\end{array}$ & $\begin{array}{l}\text { Very } \\
\text { great } \\
\text { extent }\end{array}$ & $\begin{array}{l}\text { Great } \\
\text { extent }\end{array}$ & $\begin{array}{l}\text { Moderate } \\
\text { extent }\end{array}$ & $\begin{array}{l}\text { Low } \\
\text { extent }\end{array}$ & $\begin{array}{l}\text { Not } \\
\text { at } \\
\text { all }\end{array}$ \\
\hline $\begin{array}{l}\text { There is enhancement of technologies in facilities such as water } \\
\text { tanks, storage dams/pans, drilled wells/boreholes across the county }\end{array}$ & & & & & \\
\hline $\begin{array}{l}\text { There is enhanced efforts on adopting various water technologies } \\
\text { which are well suited to the conditions of water provision in the } \\
\text { county }\end{array}$ & & & & & \\
\hline $\begin{array}{l}\text { The technologies applied by county leadership in the various areas } \\
\text { of water service have worked better with devolved government as } \\
\text { opposed to earlier under the National Government }\end{array}$ & & & & & \\
\hline $\begin{array}{l}\text { As a result of devolution, water technologies applied by county } \\
\text { leadership have been widely supported by residents in county }\end{array}$ & & & & & \\
\hline $\begin{array}{l}\text { There is adoption of more superior water technologies in the } \\
\text { county }\end{array}$ & & & & & \\
\hline Administration of devolved water services in the county has led to & & & & & \\
\hline
\end{tabular}


the development of modern technology adoption framework under active participation of all stakeholders

10) In your opinion, what improvements are needed in application of modern technology on water provision in the county?

\section{SECTION C: PLANNING}

11) From your experience while working in this county and in comparison, before and after water service was devolved to be managed at county level by Kenya Government in 2013, kindly indicate the extent to which you agree with the statements listed in the table below on a scale of 1 to 5 . Please rate each statement by ticking $(\sqrt{ })$ appropriate option against each statement provided, where $\mathbf{1}=$ Not at all, $\mathbf{2}=$ Low extent, $\mathbf{3}=$ Moderate extent, 4 $=$ Great extent and $5=$ Very great extent.

\begin{tabular}{|l|l|l|l|l|l|}
\hline Statement & $\begin{array}{l}\text { Very } \\
\text { great } \\
\text { extent }\end{array}$ & $\begin{array}{l}\text { Great } \\
\text { extent }\end{array}$ & $\begin{array}{l}\text { Mode } \\
\text { rate } \\
\text { exten } \\
\text { t }\end{array}$ & $\begin{array}{l}\text { Low } \\
\text { extent }\end{array}$ & $\begin{array}{l}\text { Not } \\
\text { at } \\
\text { all }\end{array}$ \\
\hline $\begin{array}{l}\text { a) The county uses strategic plans and County Integrated Development } \\
\text { Plan (CIDP) to guide water provision in county }\end{array}$ & & & \\
\hline $\begin{array}{l}\text { b) Devolution has led to appropriate structures being created to } \\
\text { efficiently and effectively offer water services }\end{array}$ & & & & \\
\hline $\begin{array}{l}\text { c) Devolution has enhanced appropriate allocation of resources in the } \\
\text { county budget towards water projects }\end{array}$ & & & & \\
\hline $\begin{array}{l}\text { d) Devolution has enabled optimal and on-time deliveries on water } \\
\text { projects }\end{array}$ & & & & \\
\hline
\end{tabular}

12) What improvements would you suggest concerning planning in the county especially on water provision after devolution?

\section{SECTION D: WATER PROVISION}

13) Please indicate appropriate value against each aspect stated relating to water provision in the county before and after devolution respectively.

\begin{tabular}{|l|l|l|}
\hline Aspect & Before devolution & After devolution \\
\hline $\begin{array}{l}\text { Average distance in } \\
\text { Kilometers covered by a } \\
\text { resident to access the nearest } \\
\text { water point }\end{array}$ & & \\
\hline $\begin{array}{l}\text { Average cost in Kenya } \\
\text { Shillings incurred by a } \\
\text { resident to access a 20 litter } \\
\text { jerican of water }\end{array}$ & \\
\hline $\begin{array}{l}\text { Quality of water accessed by } \\
\text { residents expressed as a } \\
\text { percentage }\end{array}$ & \\
\hline $\begin{array}{l}\text { Reliability of water access by } \\
\text { residents expressed as a } \\
\text { percentage }\end{array}$ & \\
\hline $\begin{array}{l}\text { Salinity of water accessible by } \\
\text { the residents expressed as a } \\
\text { percentage }\end{array}$ & \\
\hline $\begin{array}{l}\text { Frequency in water treatment } \\
\text { expressed as a percentage }\end{array}$ & \\
\hline
\end{tabular}


Clarity of water used by the

residents expressed as a

percentage

14) In your opinion, what suggestions/recommendations would you give to enhance water provision in the County?

\section{Copyrights}

Copyright for this article is retained by the author(s), with first publication rights granted to the journal.

This is an open-access article distributed under the terms and conditions of the Creative Commons Attribution license (http://creativecommons.org/licenses/by/4.0/). 